\title{
Sighting heterogeneity of right whales in the western North Atlantic: 1980-1992
}

\author{
Moira W. Brown*, Solange Brault ${ }^{\#}$, Philip K. Hamilton ${ }^{+}$, Robert D. Kenney ${ }^{\ddagger}$, Amy R. Knowlton ${ }^{+}$, Marilyn K. \\ MarX $^{+}$, Charles A. Mayo*, Christopher K. Slay ${ }^{+}$, Scott D. Kraus ${ }^{+* *}$ \\ Contact e-mail: mbrown@ coastalstudies.org
}

\begin{abstract}
The population of western North Atlantic right whales (Eubalaena glacialis) is distributed primarily between Florida, USA and Nova Scotia, Canada, aggregating seasonally in five geographically distinct, high-use areas. To test the effectiveness of monitoring all demographic classes (juvenile and adult males and females) of the population in these five habitat areas, an evaluation was carried out of the identification records of catalogued right whales collected between 1980 and 1992, for which the age, sex and reproductive status (for adult females) were known. The mean annual identification frequency of adult females was significantly lower than that of adult males, juvenile females and juvenile males. Among adult females, reproductively active females were seen significantly more often than expected when lactating (with a calf) than during their pregnancy or resting years. These data suggest that, while research efforts in the five high-use habitat areas have had relatively equal success at monitoring juvenile males and females and adult males, many adult females are segregated at times from the rest of the population. Lower variability in annual identification frequencies of adult females indicates that they may be more site specific in their distribution than males, particularly during the years when they are pregnant or resting from a previous pregnancy. Re-running these analyses using sighting records updated through 2000 will help determine if the trends continue to be documented regardless of changes in survey effort and patterns of habitat use of some animals.
\end{abstract}

KEYWORDS: POPULATION ASSESSMENT; MONITORING; NORTHERN HEMISPHERE; NORTH ATLANTIC; RIGHT WHALE

\section{INTRODUCTION}

Western North Atlantic right whales (Eubalaena glacialis) are known to occur seasonally in at least five geographically distinct habitat areas between Florida, USA and Nova Scotia, Canada (Fig. 1): the southeast USA between Savannah, Georgia and Cape Canaveral, Florida; the Great South Channel (between Cape Cod and Georges Bank); Cape Cod Bay; the lower Bay of Fundy; and Roseway Basin between Browns and Baccaro Banks on the southern Scotian Shelf (NMFS, 1991). Between 1980 and 1992, research efforts were conducted annually in these areas to monitor the population.

A large database of identification records of individually catalogued right whales now exists, the result of intensive photo-identification efforts since 1980 (Kraus et al., 1986a; Crone and Kraus, 1990; Hamilton and Martin, 1999). Annual sightings records of individuals of the best known portion of the population were evaluated (i.e. individuals for which both age and sex have been documented and for adult females, reproductive status). This paper investigates whether research efforts in the five high-use areas have been equally successful at monitoring the demographic classes of the population. It was assumed that the majority of right whales in the western North Atlantic have been photo-identified because the number of new identifications, other than of calves, has been low since 1989 (approximately three per year, New England Aquarium, NEAq, unpublished data). The annual sightings records of individuals from 1980 to 1992 only have been used for this study because in the following years there was a decrease or loss of survey effort in two of the high-use areas, Roseway Basin and the Great
South Channel respectively. The null hypothesis is that there is no difference in the rate of identification between groups of best known animals due to age and sex.

\section{METHODS}

The dataset was analysed for right whales for which both age and sex were known from standardised systematic surveys in the five high-use areas, from 1980 to 1992. Each identification record included the date and location, age and sex of the animal, details on associations and observed behaviours, and the name of the observer.

\section{Demographic classifications}

The sex of recognisable individuals was identified by photographic observation of the genital area, by molecular sex identification (Brown et al., 1994), or, for reproductively active adult females, by consistent association with a new-born calf (Knowlton et al., 1994). Age classification was based on year of birth, length of sighting history or, sometimes, behaviour (see below). Not all right whales could be classified at the initial identification. Observations collected in subsequent years were used to 'back-classify' some animals based on status changes observed later, i.e. reproductive states (resting and pregnant) of adult females were assigned based on the years in which they were seen with a calf.

Animals were classified into one of two age categories: juvenile or adult.

\footnotetext{
* Center for Coastal Studies, Box 1036, Provincetown, MA 02657, USA.

\# University of Massachusetts, Biology Department, 100 Morrissey Blvd., Boston, MA 02125, USA.

${ }^{+}$New England Aquarium, Central Wharf, Boston, MA 02110, USA.

¥ University of Rhode Island, Graduate School of Oceanography, Narragansett, RI 02882-1197, USA.

** List of authors is arranged alphabetically between the first and last author.
} 


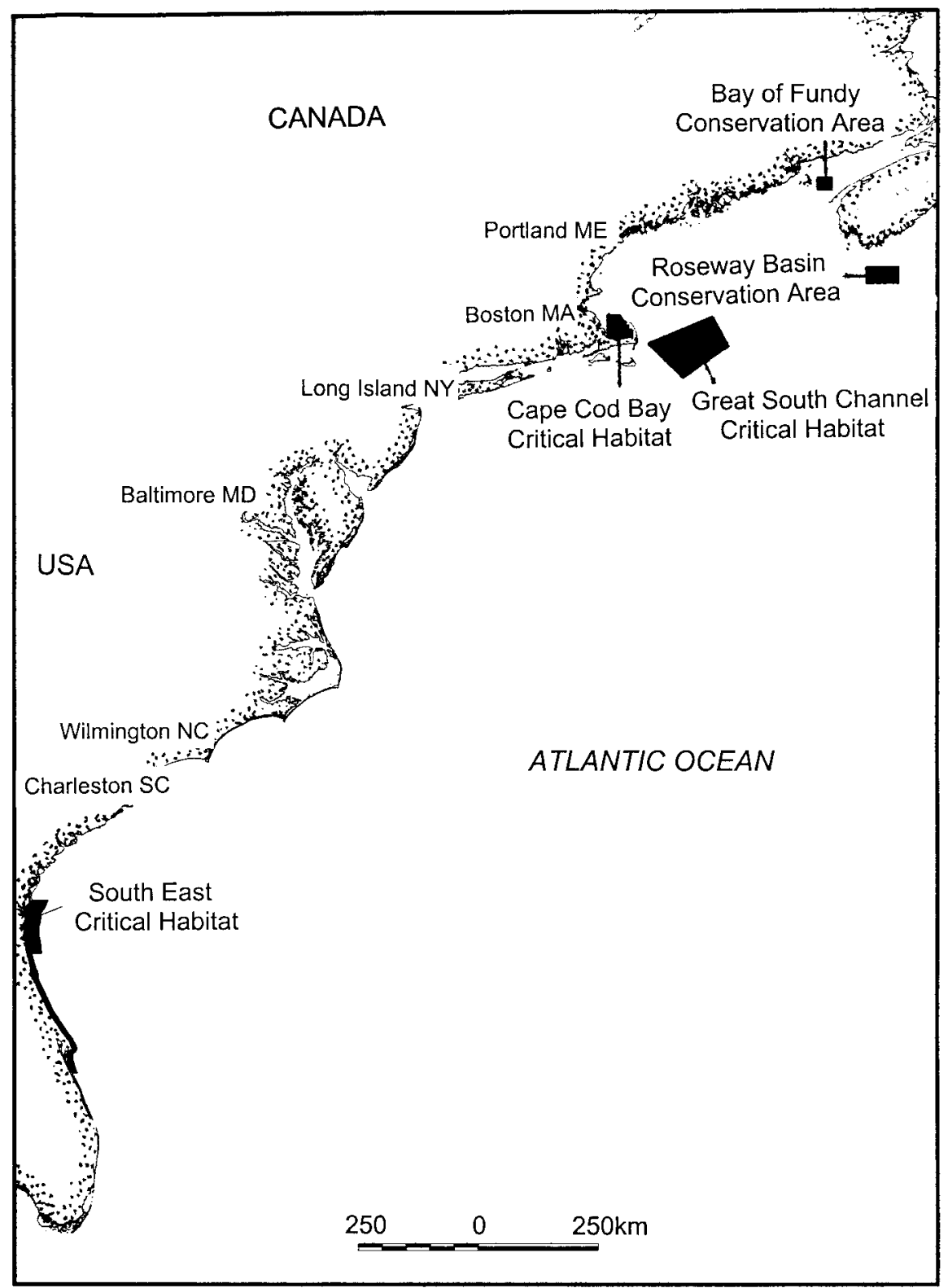

Fig. 1. Critical habitats of the Atlantic coast.

Juvenile

All pre-reproductive right whales, first seen as calves, were classified as juveniles. The mean age at sexual maturity for right whales is unknown, but Payne et al. (1990) reported that most first calves were born to female South Atlantic right whales (Eubalaena australis) of at least nine years of age. For western North Atlantic right whales, Hamilton et al. (1998) estimated the mean age of first parturition at 9.6 years $(\mathrm{SD}=2.33)$. Animals first seen as calves were therefore classified as juveniles until they reached age nine (Hamilton et al., 1998). The age classification of some animals changed from juvenile to adult during the study period.

\section{Adult}

Animals were classified as adults based on a known age of nine or more years, a sightings history of at least nine years or for males, body size and positioning as alpha males in surface-active groups (presumptive mating groups) (Kraus, 1991). For females, adults were classified by the presence of a closely associated calf (Knowlton et al., 1994). Juvenile females were back-classified as adults the year before their first known parturition if they gave birth before age nine.
Adult females were further sub-divided into reproductively active females (resting, pregnant or lactating) and non-reproductive females (nulliparous) based on their reproductive history.

\section{REPRODUCTIVELY ACTIVE ADULT FEMALES}

Adult females were considered reproductively active once they had been seen with a calf (Knowlton et al., 1994) and as lactating for the entire birthing year based on the estimated weaning time of 10-12 months for northern right whales (Hamilton et al., 1995). The length of gestation for northern right whales is not definitely known. Best (1994) estimated a gestation length of 321-397 days for right whales in the eastern South Atlantic based on the relationship between length and growth rates of foetuses. Payne (1986) assumed a year-long gestation period for right whales in the western South Atlantic, similar to that of other mysticetes (Lockyer, 1984). On this basis, it was assumed that northern right whales have a three-year interval between birthing events divided into a resting year, a year of gestation, and a year of lactation (Knowlton et al., 1994). The mean calving interval for adult female right whales from 1980-1992 was 3.67 years (Knowlton et al., 1994). Reproductively active females 
producing calves on longer than three-year intervals were classified as resting for two years (four-year interval), three years (five-year interval), or four years (six-year interval). Non-lactating adult females were back-classified as pregnant or resting in particular years on the basis of an observed subsequent birth. There are no means for determining pregnancy other than the presence of a calf the following year. Thus, the number of pregnant females is biased downward and the number of resting females is biased upwards because miscarriages or stillborn calves are unaccounted for.

\section{NON-REPRODUCTIVE (NULLIPAROUS) ADULT FEMALES}

Adult females not observed with a calf since 1980 were considered nulliparous. Included was one female, catalogue $\# 1045$, sighted with a calf in 1935 , but not seen with a calf since (Hamilton et al., 1998). Juvenile females were classified as nulliparous from age nine until the year of the first known pregnancy (back-classified by the presence of a calf the following year). The number of nulliparous females is biased downward in the first eight years of the study because there is no reliable method of estimating age for animals not first seen as calves. Adult females not seen with a calf were not classified as nulliparous until their sightings history spanned nine years.

\section{Identification frequencies}

Annual identification frequencies were calculated for each age (juvenile and adult) and sex (male and female) category by dividing the number of individuals identified each year (i.e. photographed and subsequently identified in the catalogue), by the total number in that class 'available to be seen' (i.e. known to be in the population in that year). To avoid any bias from unequal numbers of identifications of individuals in different habitat areas, which could result from unequal survey effort or variations in patterns of habitat use, each animal was scored simply as present or absent from the records within a given year, regardless of the number of times or the location where that individual was seen. Annual identification frequencies were summed to give a measurement of the probability that individuals within each category would be seen in any particular year. The identification records of adult females were further sub-divided based on their reproductive status (nulliparous, resting, pregnant and lactating).

\section{Statistical analysis}

Tests were made of the effects of age and sex on sighting probabilities, and the presence of a time trend in these probabilities, through binary logistic regression using the software package SPSS. Both age and sex were transformed into categorical variables with values of 0 or 1 (age $0=$ juvenile; age $1=$ adult; sex $0=$ male, sex $1=$ female). Through stepwise removal of parameters, their significance was tested from the ensuing changes in deviance and degrees of freedom of the regression model. Regression parameter values for the logit models were estimated by maximum-likelihood. Given the large number of individuals $(n=337)$, each whale's presence or absence in a given year was treated as one case, regardless of whether the same whale was observed in previous or later years, i.e. each observation was treated as independent from others of the same individual. Effects due to individual histories were therefore not tested here.

Differences in the rate of identification between adult females in different reproductive states were examined using a chi-square analysis. Using the mean calving interval of 3.67 years (Knowlton et al., 1994) expected values were generated for sightings based on the null hypothesis that there was no difference in the rate of identification of adult females due to reproductive state. It was assumed that adult females were pregnant for one year, lactating for one year and resting for 1.67 years. These values were tested against the actual number of adult females seen in each of the three reproductive categories.

\section{RESULTS}

In total, there were 6,209 sightings of 1,700 right whales representing 337 catalogued individuals identified between 1980 and 1992; $92 \%$ of those sightings were from survey efforts in the five high-use habitat areas. Of those 337, both age and sex were known for 231 animals (69\% of the known population). Following each of these known individuals over their respective periods of availability for sighting, yielded 1,430 records (Table 1 ). Table $2 \mathrm{a}$ presents the results from the logistic regression; total sighting frequency estimates by age and sex from the regression are given in Table $2 b$. No significant time trend in presence or absence of known individuals was found, and age alone did not explain a

Table 1

Number of right whales of known age and sex identified $(n=858)$ as a proportion of the number available to be identified $(n=1,430)$ within each demographic category by year. Multiple indications within a year have been eliminated.

\begin{tabular}{|c|c|c|c|c|c|c|c|c|c|c|c|c|}
\hline & \multicolumn{3}{|c|}{ Adult females } & \multicolumn{3}{|c|}{ Juvenile females } & \multicolumn{3}{|c|}{ Adult males } & \multicolumn{3}{|c|}{ Juvenile males } \\
\hline & Seen & Available & Frequency & Seen & Available & Frequency & Seen & Available & Frequency & Seen & Available & Frequency \\
\hline 1980 & 9 & 17 & 0.53 & 0 & 2 & 0.00 & 0 & 1 & 0.00 & 0 & 0 & 0.00 \\
\hline 1981 & 9 & 21 & 0.43 & 3 & 4 & 0.75 & 0 & 2 & 0.00 & 0 & 1 & 0.00 \\
\hline 1982 & 16 & 29 & 0.55 & 3 & 6 & 0.50 & 2 & 4 & 0.50 & 4 & 7 & 0.57 \\
\hline 1983 & 13 & 35 & 0.37 & 5 & 10 & 0.50 & 2 & 3 & 0.67 & 6 & 11 & 0.55 \\
\hline 1984 & 22 & 36 & 0.61 & 9 & 12 & 0.75 & 1 & 3 & 0.33 & 9 & 12 & 0.75 \\
\hline 1985 & 22 & 38 & 0.58 & 7 & 16 & 0.44 & 3 & 5 & 0.60 & 8 & 18 & 0.44 \\
\hline 1986 & 22 & 41 & 0.54 & 14 & 17 & 0.82 & 8 & 8 & 1.00 & 19 & 21 & 0.90 \\
\hline 1987 & 20 & 46 & 0.43 & 13 & 19 & 0.68 & 10 & 12 & 0.83 & 18 & 27 & 0.67 \\
\hline 1988 & 26 & 50 & 0.52 & 23 & 26 & 0.88 & 32 & 34 & 0.94 & 27 & 31 & 0.87 \\
\hline 1989 & 37 & 59 & 0.63 & 21 & 24 & 0.88 & 50 & 61 & 0.82 & 30 & 33 & 0.91 \\
\hline 1990 & 35 & 61 & 0.57 & 25 & 33 & 0.76 & 30 & 71 & 0.42 & 21 & 32 & 0.66 \\
\hline 1991 & 31 & 65 & 0.48 & 20 & 33 & 0.61 & 48 & 78 & 0.62 & 22 & 34 & 0.65 \\
\hline 1992 & 26 & 68 & 0.38 & 23 & 35 & 0.66 & 35 & 81 & 0.43 & 19 & 37 & 0.51 \\
\hline Total identified & 288 & & & 166 & & & 221 & & & 183 & & \\
\hline Total available & & 566 & & & 237 & & & 363 & & & 264 & \\
\hline Mean id frequency & & & 0.51 & & & 0.63 & & & 0.55 & & & 0.62 \\
\hline Standard deviation & & & 0.08 & & & 0.24 & & & 0.32 & & & 0.25 \\
\hline
\end{tabular}


Table $2 \mathrm{a}$

Results of the stepwise binary logistic regression of the dependent variable, presence of a whale in the sighting records, against year, age, sex and age $x$ sex interaction term. Value of coefficients $B$ are for the log-odd ratio transforms $(\log (y / 1-y))$. Wald values test for significance of parameters, given the change in degrees of freedom (df) when parameters are added or removed from the model. Parameters contributing significantly to the model are in bold.

\begin{tabular}{lccccc}
\hline Variables & $B$ & SF of B & Wald & df & Significance \\
\hline Constant & $\mathbf{0 . 8 3 1}$ & $\mathbf{0 . 0 9 7}$ & $\mathbf{7 3 . 1 5 3}$ & $\mathbf{1}$ & $<\mathbf{0 . 0 0 1}$ \\
Year & - & - & 1.240 & 1 & 0.266 \\
Sex & - & - & 0.031 & 1 & 0.860 \\
Age & $\mathbf{- 0 . 3 8 9}$ & $\mathbf{0 . 1 4 5}$ & $\mathbf{7 . 1 9 7}$ & $\mathbf{1}$ & $\mathbf{0 . 0 0 7}$ \\
Age by Sex & $\mathbf{- 0 . 4 0 7}$ & $\mathbf{0 . 1 3 7}$ & $\mathbf{8 . 8 8 8}$ & $\mathbf{1}$ & $\mathbf{0 . 0 0 3}$ \\
Interaction & & & & & \\
\hline
\end{tabular}

significant amount of variation in the data. The final model includes an intercept (the constant), age, and the interaction of age by sex, all of which are highly significant $(p<0.01)$. The intercept alone describes the probability of juvenile males (i.e. age $=0$ and sex $=0$ ) being present. Juvenile females have the same predicted probability as juvenile males, because sex has no effect on presence or absence from the records, unless individuals are adults (i.e. through the interaction term). Adults have a lower probability of being present than juveniles, and adult females have a lower probability of presence than adult males.

The relative numbers of the three categories (pregnancy, lactation and resting) of reproductively active adult females were examined to determine what proportion of adult females seen could be attributed to a phase of the reproductive cycle (Table 3a). It was tested whether their proportions were as expected given a calving interval of 3.67 years and an even chance of observations among categories.
Table $2 b$

Observed frequencies (from Table 1) and probabilities of presence predicted from the regression model in Table $2 \mathrm{a}$ of each age and sex calegory.

\begin{tabular}{lcccccc}
\hline & \multicolumn{2}{c}{ Observed frequencies } & & \multicolumn{2}{c}{ Predicted probability of presence } \\
\cline { 2 - 3 } \cline { 5 - 6 } Sex & Juvenile & Adult & & Juvenile & Adult \\
\hline Male & 0.693 & 0.609 & & 0.697 & 0.509 \\
Female & 0.700 & 0.509 & & 0.697 & 0.609 \\
\hline
\end{tabular}

The proportions were highest among lactating animals and lowest among pregnant ones. Among the three classes of reproductively active adult females, lactating females were seen significantly more often than expected $\left(\chi^{2}=76.917\right.$, $p<0.001)$ and pregnant and resting females significantly less often than expected $\left(\chi^{2}=9.508, p=0.002\right),\left(\chi^{2}=19.508\right.$, $p=0.001)$ respectively (Table $3 b)$. It was not possible to calculate identification frequencies for adult females by reproductive status because it was unclear how many were available to be seen in each category. Only the total numbers of reproductively active adult females or nulliparous females were known.

The individual sightings records of reproductively active adult females were further examined to assess their use of the southeastern USA calving ground. Of 65 known reproductively active adult females that have produced 145 calves between 1980 and 1992, 16 (25\%) have never been seen on the calving ground with a calf and only 19 (13\%) have been seen in the southeast with all of their calves. There were $56(86 \%)$ which were available to be monitored (identified) both the year before parturition (during pregnancy) and the year after weaning (resting) for 124 calvings. In a significant portion of these calvings (51\%),

\section{Table 3a}

Number of individual adult females identified annually. The annual sightings of reproductively active females were further subdivided into resting, pregnant or lactating status. The number of non-reproductive adult females (nulliparous) was subtracted from the total adult females seen to obtain a proportion of reproductive females seen by reproductive status $(n=256$ ). The percentages of resting, pregnant and lactating females are given in brackets. Identification frequencies were not calculated for reproductively adult females because it was not known how many were available to be seen in each category.

\begin{tabular}{|c|c|c|c|c|c|}
\hline \multirow[b]{2}{*}{ Year } & \multirow{2}{*}{$\begin{array}{c}\text { Adult females } \\
\text { No. seen/available }\end{array}$} & \multirow{2}{*}{$\frac{\text { Non-reproductive }}{\text { Nulliparous seen/available }}$} & \multicolumn{3}{|c|}{ Reproductively active } \\
\hline & & & Resting (\%) & Pregnant $(\%)$ & Lactating $(\%)$ \\
\hline 1980 & $9 / 17$ & $2 / 4$ & $1(14.3)$ & $1(14.3)$ & $5(71.4)$ \\
\hline 1981 & $9 / 21$ & $0 / 4$ & $0(0.0)$ & $2(22.2)$ & $7(77.7)$ \\
\hline 1982 & $16 / 29$ & $1 / 4$ & $3(20.0)$ & $2(13.3)$ & $10(66.6)$ \\
\hline 1983 & $13 / 35$ & $0 / 4$ & $3(23.0)$ & $1(7.7)$ & $9(69.2)$ \\
\hline 1984 & $22 / 36$ & $0 / 4$ & $6(27.3)$ & $4(18.2)$ & $12(54.5)$ \\
\hline 1985 & $22 / 38$ & $3 / 4$ & $6(31.6)$ & $2(10.5)$ & $11(57.9)$ \\
\hline 1986 & $22 / 41$ & $0 / 4$ & $7(31.8)$ & $2(9.1)$ & $13(59.1)$ \\
\hline 1987 & $20 / 46$ & $2 / 3$ & $6(33.3)$ & $1(5.5)$ & $11(61.1)$ \\
\hline 1988 & $26 / 50$ & $2 / 3$ & $9(37.5)$ & $8(33.3)$ & $7(29.2)$ \\
\hline 1989 & $37 / 59$ & $8 / 9$ & $9(28.6)$ & $3(10.7)$ & $17(60.7)$ \\
\hline 1990 & $35 / 61$ & $6 / 10$ & $7(24.1)$ & $10(34.5)$ & $12(41.4)$ \\
\hline 1991 & $31 / 65$ & $4 / 9$ & $4(14.8)$ & $7(25.9)$ & $16(59.3)$ \\
\hline 1992 & $26 / 68$ & $4 / 10$ & $8(36.4)$ & $1(4.5)$ & $13(59.1)$ \\
\hline No. seen/available & $288 / 566$ & $32 / 72$ & 69 & 44 & 143 \\
\hline Mean percentage & & & 24.8 & 16.1 & 59.0 \\
\hline Standard deviation & & & 10.6 & 10.0 & 12.6 \\
\hline
\end{tabular}

Table $3 b$

Results of the chi-square analysis on the three categories of reproductively active adult females using observed frequencies from Table 3a, a calving interval of 3.67 years to generated expected values and an even chance of observations.

\begin{tabular}{lccc}
\hline Frequencies & Resting & Pregnant & Lactating \\
\hline Observed & 69 & 44 & 143 \\
Expected & 116.49 & 69.75 & 69.75 \\
$\chi^{2}$ & 19.508 & 9.508 & 76.917 \\
Significance & $<0.001$ & 0.002 & $<0.001$ \\
\hline
\end{tabular}


adult females were only seen in the year in which they gave birth $\left(63 / 124, \chi^{2}=19.898, p<0.001\right)$. Reproductively active adult females were identified during the year before parturition for $25 \%(30 / 124)$ of calvings, and the year after weaning for $11 \%(14 / 124)$. There were only 17 calvings $(13 \%)$ where adult females were identified both the year before and the year after. Of the 61 calvings for which adult females were identified before and/or after parturition, most of these identifications $(61 \%)$ were recorded in the spring in Cape Cod Bay or the Great South Channel, but not during the summer and autumn in the Bay of Fundy or Roseway Basin (Brown, 1994). On average, $72 \%$ of the cow-calf pairs seen in other areas between 1989 and 1992 (years of increased survey effort in the calving ground) were also seen the same year in the southeast USA (Kraus et al., 1993).

\section{DISCUSSION}

The similarity in the frequency of identifications of male and female juveniles and adult males (Table 1) demonstrates that survey efforts in the five high-use seasonal habitat areas have had relatively equal success in monitoring these segments of the catalogued right whale population over the 13-year study period. The same monitoring efforts however, have yielded significantly lower identifications for adult females suggesting that many are segregated from the rest of the population, particularly during the inter-birth years. Overall, these analyses indicate that the identification rate among the best known animals is not homogeneous by age and sex. There is now strong evidence for segregation by age, by sex (in adults) and by reproductive state (for adult females), in the western North Atlantic right whale population.

There are several ecological and behavioural reasons why adult female right whales might be seen less often in the high-use areas than other age/sex classes. One is that there could be a dietary difference compared to males or juveniles due to the higher energy demand while producing and rearing offspring (Lockyer, 1984). Female right whales invest heavily in their offspring, giving birth in the winter months to a calf that averages $4.5 \mathrm{~m}$ in length and about $800 \mathrm{~kg}$ in weight. By the time the calf is weaned it may be $8.5 \mathrm{~m}$ long with an estimated weight of $5,000 \mathrm{~kg}$ (NEAq, unpublished data). Lactation is estimated to last 10-12 months (Hamilton et al., 1995) followed by a year or more of rest, presumably to replenish energy reserves depleted during lactation (Lockyer, 1984). Adult females may also be feeding on different prey types at different times of their reproductive cycle. Dietary differences between pregnant and lactating animals have been found for spotted dolphins, Stenella attenuata (Bernard and Hohn, 1989) and harbour porpoises, Phocoena phocoena (Recchia and Read, 1989).

Another possible reason could be avoidance of areas where other right whales aggregate, especially those areas where there is a high percentage of males. Given the high costs of reproduction (both in terms of time and energy) and the prevalence of surface-active groups in the northern habitat areas (Kraus, 1991), it may be beneficial for non-calving adult females to avoid areas where males predominate, until they are ready to reproduce. This might explain the low numbers of adult females seen on Roseway Basin, the only area where juvenile and adult males predominate and the area with the highest occurrence of surface-active groups (Kraus and Brown, 1992; Brown, 1994).

The only known calving ground for right whales in the southeastern USA was identified in the early 1980s (Kraus et al., 1986b) but speculation on additional calving grounds exists in the North Atlantic. In the western South Atlantic population, two adult females were observed with newborns in a second calving ground in the waters off the coast of Brazil (Best et al., 1993). These females, observed in previous years with calves in Argentine waters, were using an alternative calving area in some years. In the western North Atlantic, the evidence suggests that the southeastern USA is certainly the primary, and possibly the only, calving area for this species. There have been no confirmed reports of calvings in other areas. Between 1980 and 1992, 74\% of the reproductively active adult females were seen in the southeast. The remaining cow-calf pairs may have also used this area but experienced early (before January) or late season (after the end of March) births.

However, annual counts of cow-calf pairs seen in the southeastern USA have increased with increasing survey effort in the latter years since 1989. The size of the survey area in the early years (pre-1989) was large, ranging from North Carolina to southern Florida. In the latter years, a similar amount of effort over a longer season was concentrated in a smaller area between Savannah, Georgia and Cape Canaveral, Florida, suggesting the increase in the annual counts reflects a concentrated distribution of animals over a protracted season in this region.

There have been no identifications of non-calving adult females in the southeastern USA in the year preceding or following their parturition. However, there were sightings of reproductively active adult females in a year in which they were expected to give birth, but in which no calf was recorded. These individuals may have experienced a near-term abortion or a still birth. Several deaths of young right whales (less than $5 \mathrm{~m}$ in length) have been documented in the coastal waters of Florida and Georgia (Kraus, 1990). In 1989, five adult females were seen in Florida and later that year in other areas without calves, and three neonatal mortalities were recorded in southeastern USA. Analysis of DNA from tissue samples collected from stranded neonates and those adult females could reveal the maternal parentage resulting in a better assessment of reproductive success of females and providing an explanation for the longer calving intervals observed in some adult females.

Research efforts between 1980 and 1992 were concentrated in the five high-use areas because of the remarkable consistency with which right whales were seen there. Right whales migrate to areas with high spring, summer and autumn concentrations of Calanus finmarchicus copepods (Winn et al., 1986; Wishner et al., 1988; Murison and Gaskin, 1989; Mayo and Marx, 1990; Woodley, 1992; Kenney, 1994; Kenney et al., 1995). Since 1992, there have been several interesting variations in the general pattern of seasonal movements. For example, no right whales were seen in the Great South Channel in the spring of 1992 (Kenney et al., 1995). Analysis of plankton samples suggested the whales' absence might have been related to a shift in zooplankton dominance, caused by significantly reduced water temperatures and a delay in the development of the usual hydrographic structure of the region (Kenney, 1994). No right whales were seen in surveys of Roseway Basin in August of 1993, 1994, 1996-1999, nor were there any sightings of sei whales (Balaenoptera borealis), a species commonly seen in association with right whales in this area and also considered (Mitchell, 1975) to be a primarily calanoid copepod feeder in the North Atlantic. Water surface temperatures in 1993 were $4-6^{\circ} \mathrm{C}$ lower than in previous years (NEAq, unpublished data).

In another respect, reliance upon specific areas makes whales vulnerable to fluctuations in the availability of prey. 
Assuming that the whale's selection of these feeding areas is based on the density of food items, then it is not necessarily the distinct area that is important but the set of oceanographic conditions that result in the concentration of food to sufficient densities required by right whales, as suggested by Winn et al. (1986). Documented shifts in seasonal distribution in the 1986 summer in Massachusetts Bay (Hamilton and Mayo, 1990), in 1992 in the Great South Channel (Kenney, 1994), and in the Bay of Fundy and Roseway Basin from 1993 to 1999 (NEAq, unpublished data), may indicate flexibility in their use of available spring, summer and autumn feeding areas. Under large shifts in oceanographic patterns, movements among and changes in foraging areas by individual whales are likely, as are differences in habitat use among age and sex categories. Re-running these analyses using sightings records updated through 2000 will help determine if the trends continue to be documented regardless of changes in survey effort and patterns of habitat use of some animals.

\section{ACKNOWLEDGEMENTS}

The data source for these analyses was the North Atlantic Right Whale Consortium Catalogue curated at the New England Aquarium, Boston, Massachusetts. We would like to thank M.J. Crone, J.N Ciano and the over 100 volunteers and research assistants who have helped collect data and analyse over thousands of photographs of right whales since 1980. Additional data were contributed to the Right Whale Catalogue from the Center for Coastal Studies, Woods Hole Oceanographic Institution, University of Rhode Island and the Department of Environmental Protection in Florida and the Department of Natural Resources in Georgia. This work was carried out with support from the Natural Sciences and Engineering Research Council of Canada via an operating grant to D.E. Gaskin. Thank you to H. Caswell, P. Corkeron, M.M. Ferguson, D.E. Gaskin, D.M. Lavigne, A.J. Read and B.N. White whose comments improved the manuscript.

\section{REFERENCES}

Bernard, H.J. and Hohn, A.A. 1989. Differences in feeding habits between pregnant and lactating spotted dolphins (Stenella attenuata). J. Mammal. 70(1):211-5.

Best, P.B. 1994. Seasonality of reproduction and the length of gestation in southern right whales Eubalaena australis. J. Zool., Lond. 232:175-89.

Best, P.B., Payne, R., Rowntree, V., Palazzo, J.T. and Both, M.D. 1993. Long-range movements of South Atlantic right whales, Eubalaena australis. Mar. Mammal Sci. 9(3):227-34.

Brown, M.W. 1994. Population structure and seasonal variation of North Atlantic right whales (Eubalaena glacialis). Ph.D. Thesis, University of Guelph, Ontario, Canada.

Brown, M.W., Kraus, S.D., Gaskin, D.E. and White, B.N. 1994. Sexual composition and analysis of reproductive females in the North Atlantic right whale, Eubalaena glacialis, population. Mar. Mammal Sci. 10(3):252-65.

Crone, M.J. and Kraus, S.D. (eds.). 1990. Right Whales (Eubalaena glacialis), in the Western North Atlantic: A Catalog of Identified Individuals. New England Aquarium, Boston. 223pp.

Hamilton, P.K. and Martin, S.M. 1999. A Catalog of Identified Right Whales from the Western North Atlantic: 1935-1997. New England Aquarium, Boston. 27pp. [382 plates].

Hamilton, P.K. and Mayo, C.A. 1990. Population characteristics of right whales (Eubalaena glacialis) observed in Cape Cod and Massachusetts Bays, 1978-1986. Rep. int. Whal. Commn (special issue) $12: 203-8$.
Hamilton, P.K., Marx, M.K. and Kraus, S.D. 1995. Weaning in North Atlantic right whales. Mar. Mammal Sci. 11(3):386-90.

Hamilton, P.K., Knowlton, A.R., Marx, M.K. and Kraus, S.D. 1998. Age structure and longevity in North Atlantic right whales (Eubalaena glacialis). Mar. Ecol. Prog. Ser. 171:285-92.

Kenney, R.D. 1994. Anomalous 1992 spring and summer distributions of right whales (Eubalaena glacialis) and other cetaceans in continental shelf waters off the northeastern United States and adjacent Canada. Final Report to US Marine Mammal Commission, Washington, DC, Contract No. T94070648. 65pp.

Kenney, R.D., Winn, H.E. and Macaulay, M.C. 1995. Cetaceans in the Great South Channel, 1979-1989: Right whale (Eubalaena glacialis). Cont. Shelf Res. 15(4-5):385-414.

Knowlton, A.R., Kraus, S.D. and Kenney, R.D. 1994. Reproduction in North Atlantic right whales (Eubalaena glacialis). Can. J. Zool. 72(7):1,297-305.

Kraus, S.D. 1990. Rates and potential causes of mortality in North Atlantic right whales (Eubalaena glacialis). Mar. Mammal Sci. 6(4):278-91.

Kraus, S.D. 1991. Mating strategies in the North Atlantic right whale, (Eubalaena glacialis). MSc Thesis, University of Massachusetts at Boston, Boston, Massachusetts. 58pp.

Kraus, S.D. and Brown, M.W. 1992. Right whales on the southern Scotian Shelf. The right whale in the western North Atlantic: A science and management workshop. Northeast Fisheries Science Center Reference Document 92-05. NOAA/National Marine Fisheries Service, Woods Hole, Massachusetts. 88pp.

Kraus, S.D., Moore, K.E., Price, C.A., Crone, M.J., Watkins, W.A., Winn, H.E. and Prescott, J.H. 1986a. The use of photographs to identify individual North Atlantic right whales (Eubalaena glacialis). Rep. int. Whal. Commn (special issue) 10:145-51.

Kraus, S.D., Prescott, J.H., Knowlton, A.R. and Stone, G.S. 1986b. Migration and calving of right whales (Eubalaena glacialis) in the western North Atlantic. Rep. int. Whal. Commn (special issue) 10:139-44.

Kraus, S.D., Kenney, R.D., Knowlton, A.R. and Ciano, J.N. 1993. Endangered right whales of the southwestern North Atlantic. Final Report, Minerals Management Service Contract No. 14-35-0001-30486. Edgerton Research Laboratory, New England Aquarium, Boston, MA.

Lockyer, C. 1984. Review of baleen whale (Mysticeti) reproduction and implications for management. Rep. int. Whal. Commn (special issue) 6:27-50

Mayo, C.A. and Marx, M.K. 1990. Surface foraging behaviour of the North Atlantic right whale, Eubalaena glacialis, and associated zooplankton characteristics. Can. J. Zool. 68:2,214-20.

Mitchell, E.D. 1975. Trophic relationships and competition for food in northwest Atlantic whales. Proc. Can. Soc. Zool. Ann. Mtg :123-33.

Murison, L.D. and Gaskin, D.E. 1989. The distribution of right whales and zooplankton in the Bay of Fundy, Canada. Can. J. Zool. 67(6):1,411-20.

National Marine Fisheries Service. 1991. Recovery plan for the northern right whale (Eubalaena glacialis). Prepared by the Right Whale Recovery Team for the NMFS, 1335 East-West Highway, Silver Spring, MD 20910, USA. vi+86pp.

Payne, R. 1986. Long term behavioral studies of the southern right whale (Eubalaena australis). Rep. int. Whal. Commn (special issue) 10:161-7.

Payne, R., Rowntree, V., Perkins, J.S., Cooke, J.G. and Lankester, K. 1990. Population size, trends and reproductive parameters of right whales (Eubalaena australis) off Peninsula Valdes, Argentina. Rep. int. Whal. Commn (special issue) 12:271-8.

Recchia, C.A. and Read, A.J. 1989. Stomach contents of harbour porpoises, Phocoena phocoena (L.), from the Bay of Fundy. Can. J. Zool. 67:2140-6.

Winn, H.E., Price, C.A. and Sorensen, P.W. 1986. The distributional biology of the right whale (Eubalaena glacialis) in the western North Atlantic. Rep. int. Whal. Commn (special issue) 10:129-38.

Wishner, K., Durbin, E., Durbin, A., MacAulay, M., Winn, H. and Kenney, R. 1988. Copepod patches and right whales in the Great South Channel off New England. Bull. Mar. Sci. 43(3):825-44.

Woodley, T.A. 1992. A characterisation of the North Atlantic right (Eubalaena glacialis) and finback (Balaenoptera physalus) whale habitat in the lower Bay of Fundy, Canada. MSc Thesis, University of Guelph, Guelph, Ontario. 104pp. 